\title{
Transcription of equine chorionic gonadotropin/luteinizing hormone $\beta$ subunit gene in the endometrium of non-pregnant mares
}

\author{
Denny Böttcher', Hilke Gräfel, Gerolf Zimmermann², Henry Alexander², Christin Ellenberger' and Heinz-Adolf Schoon? \\ 'Institute of Pathology, University of Leipzig, Germany \\ ${ }^{2}$ Department of Obstetrics and Gynaecology, Division of Human Reproduction and Endocrinology, University of Leipzig, Germany
}

\begin{abstract}
Summary: The aim of this study was to determine if the gene of the equine chorionic gonadotropin (eCG)/equine luteinizing hormone $(\mathrm{eLH}) \mathrm{b}$ subunit is transcribed in the non-gravid endometrium of the mare, since recent discoveries have shown that human chorionic gonadotropin is synthesized in the uterus of non-pregnant women. Therefore, native endometrial tissue of 9 mares was investigated by RT-PCR to detect mRNA of the eCG/eLH b subunit gene. Formalin-fixed, paraffin-embedded samples of these uteri were used for histological evaluation of the stage of the reproductive cycle (secretory or proliferative morphology of the endometrium). In addition, immunohistochemistry was perform-ed on histological slides of both the proliferative and secretory phase of the endometrial cycle, using a polyclonal rabbit antieCGb/eLHb antibody. PCR revealed transcription of the eCG/eLH b subunit gene in 6 samples, with mRNA being detectable in secretory as well as proliferative phase endometria. Immunohistochemistry revealed cytoplasmic presence of the eCG/eLH b subunit, especially in the epithelial cells of the uterine glands. Though the biological relevance of these findings has yet to be elucidated, our results suggest a possible paracrine role of eCG/eLH in the endometrium of the mare.
\end{abstract}

Keywords: mare / eCG / eLH / mRNA / horse / uterus / PCR / immunohistochemistry / reproduction

Correspondence: Dr. Denny Böttcher, Institut für Veterinär-Pathologie, Universität Leipzig, An den Tierkliniken 33, 04103 Leipzig, Germany, denny.boettcher@vetmed.uni-leipzig.de

Citation: Böttcher D., Gräfe H., Zimmermann G., Alexander H., Ellenberger C., Schoon H.-A. (2014) Transcription of equine chorionic gonadotropin/luteinizing hormone b subunit gene in the endometrium of non-pregnant mares. Pferdeheilkunde 30, 19-25

\section{Introduction}

Chorionic gonadotropins (CGs) exist in only a few species including humans, non-human primates, horses, donkeys and zebras. In equids, CGs may differ among species regarding their molecular structure and/or biological properties (Aggarwal et al. 1980, Leigh and Stewart 1990, McFarlane et al. 1991b, Chopineav et al. 1999). Equine (i.e. horse) chorionic gonadotropin (eCG) is a heterodimeric glycoprotein that consists of $\alpha$ and $\beta$ subunits joined non-covalently (Papkoff 1974). The $\alpha$ subunit of eCG is identical to the $\alpha$ subunits of some pituitary hormones, namely two other gonadotropins (equine luteinizing hormone, eLH, and equine follicle-stimulating hormone, eFSH) and equine thyroid-stimulating hormone (eTSH). On the contrary, the $\beta$ subunits of these hormones differ and are therefore supposed to be relevant for their specific biological activities (Papkoff 1974, Pierce and Parsons 1981). In contrast to human chorionic gonadotropin (hCG) and human luteinizing hormone $(h L H)$, the $\beta$ subunits of eCG and eLH are encoded by a single gene (Sherman et al. 1992, Bousfield et al. 1996, de Mestre et al. $2011)$. Therefore, both equine subunits share the same amino acid sequence (Bousfield et al. 1987, Sugino et al. 1987). Differential posttranslational modification results in different carbohydrate moieties of eCG and eLH $\beta$ subunits (Matsui et al. 1991, Murphy and Martinuk 1991). However, both equine hormones have been shown to possess similar antigenic properties (Wooding et al. 2001).

The so-called endometrial cups are generally believed to be the sole source of eCG in the mare (de Mestre et al. 2011).
The endometrial cup cells are specialized cells originating from the chorionic girdle of the trophoblast (Allen and Moor 1972). Cells of this discrete band encircling the equine conceptus invade the uterus between 36 and 38 days of gestation, followed by formation of the endometrial cups (Allen et al. 1973). In women, hCG is also known to be of fetal origin, at least from a 'classical' point of view (Cole 2012). Over the last 15 years, not only placental tissue of maternal origin, but also secretory endometrium during the normal menstrual cycle has been shown to be a source of hCG. The hormone is supposed to be essential for early pregnancy due to paracrine induction of secretory transformation and predecidualization as well as local immunomodulatory effects. Therefore, hCG seems to play an important role for preparation of embryo implantation. Thus, immunohistochemical investigation of endometrial biopsy specimens regarding cycle synchronicity of hCG production can be used for fertility evaluation (Alexander et al. 1998, Wolkersdörfer et al. 1998, Schumacher et al. 2009, Zimmermann et al. 2003, 2009, 2012). Based on these recent discoveries in human reproduction, the aim of this study was to determine if the eCG/eLH $\beta$ subunit gene is transcribed in the non-gravid endometrium of the mare.

\section{Materials and methods \\ Endometrial tissue samples}

Endometrial specimens were obtained from 9 non-pregnant mares (3-18 years of age) that were euthanized or had died 
spontaneously and were submitted for necropsy. All samples were collected 1.5-2.5 hours after the animals had died. The specimens were divided into two portions: one part was snap frozen in liquid nitrogen immediately after collection and stored at $-80^{\circ} \mathrm{C}$ until molecular biological investigations were performed; the second part was fixed in $4 \%$ neutral buffered formalin for at least 24 hours, embedded in paraplast, sectioned at 3-4 $\mu \mathrm{m}$ and stained with hemalum and eosin (Mulisch and Welsch 2010). The samples were then examined microscopically to identify inflammatory (endometritis) or degenerative (endometrosis, angiosclerosis) alterations, and to determine the functional morphology (different stages of proliferative and secretory phase ) of the endometrium according to Kenney and Doig (1986) and Schoon et al. (1992, 1997).

\section{Molecular biological investigations}

The frozen tissue samples were used for reverse transcriptase polymerase chain reaction (RT-PCR), applying a primer pair consisting of the forward primer $5^{\prime}$-CTG TGG ATG CTG CTG AGT GT-3' and the reverse primer 5'-ATG AGA GGA ACG TCT GCT GG-3' (amplicon size: 462 base pairs, bp). For the design of the primer pair, predicted mRNA sequences for equus caballus luteinizing hormone beta polypeptide were obtained from NCBI Genbank (www.ncbi.nlm.nih.gov/Genbank/) and the primer design program (primer 3) was used. For assessment of the quality of the mRNA samples, the expression of the housekeeping gene of glyceraldehyde-3phosphate dehydrogenase (GAPDH) was determined using a primer pair specified by Erdmann et al. (2007) for the detection of an amplicon of $567 \mathrm{bp}$. These authors had used this primer pair for the ascertainment of bovine GAPDH mRNA, but it is also suitable for equine tissue based on the high sequence homology (92.8\%).

The total mRNA was extracted from the frozen tissue using PeqGold, RNA Pure ${ }^{\mathrm{TM}}$ according to the guidelines of the manufacturer (Peqlab Ltd., Sarisbury Green, UK). The amount of extracted RNA was measured by photometry (260/ $280 \mathrm{~nm})$.

Moloney Murine Leukemia Virus reverse transcriptase (M-MLV RT) (Promega, Madison, WI, USA) and random primer (Invitrogen, Carlsbad, CA, USA) were used for reverse transcription of mRNA to first-strand cDNA by means of a standardized method. The transcription was carried out with $5 \mu \mathrm{g}$ of mRNA in a $20 \mu$ l reaction mixture.

cDNA amplification was performed in a $25 \mu$ l reaction mixture. For the detection of eCG $\beta / \mathrm{eLH} \beta$, the reaction mixture contained $1 \mu \mathrm{l}$ of generated cDNA, $0.2 \mathrm{mM}$ of dNTP mix (Roche, Mannheim, Germany), $0.4 \mu \mathrm{M}$ of sense and antisense primers (Eurofins MWG, Ebersberg, Germany), $1.5 \mathrm{mM} \mathrm{MgCl}$ (Roche), $2.5 \mu$ l of PCR buffer (10x, Roche) and $0.5 \mathrm{U}$ of TaqDNA polymerase (Roche). Reaction mixtures with replacement of cDNA by diethylpyrocarbonate (DEPC) water were used to rule out DNA contamination. The amplification steps were performed in a PTC 200 Thermo cycler (MJ Research, St Brun, Canada) and included initial denaturation (5 min, $\left.95^{\circ} \mathrm{C}\right), 35$ cycles of denaturation $\left(30 \mathrm{~s}, 95^{\circ} \mathrm{C}\right)$, annealing $\left(45 \mathrm{~s}, 50^{\circ} \mathrm{C}\right)$ and extension $\left(30 \mathrm{~s}, 72^{\circ} \mathrm{C}\right)$, as well as final elongation $\left(10 \mathrm{~min}, 72^{\circ} \mathrm{C}\right.$ ) and cooling to $4^{\circ} \mathrm{C}$. GAPDH PCR was performed under the same conditions.
The amplicons were separated in a $1 \%$ agarose gel using Gene Ruler $^{\text {TM }} 100$ bp DNA ladder (Fermentas, St. Leon-Rot, Germany) as a molecular marker. The PCR products were stained with ethidium bromide (Carl Roth, Karlsruhe, Germany) or Gel Red Nucleic Acid Stain (Biotium, Brussels, Belgium) and bands were visualized by ultraviolet light using a BioRad Detection System (ChemiDocXRS).

Sequencing was performed on 5 selected cases to confirm the specificity of the eCG $\beta /$ eLH $\beta$ PCR products, which were purified with a Gel extraction kit (Qiagen, Hilden, Germany) and sequenced at the Interdisciplinary Centre for Clinical Research (IZKF), Leipzig, Germany.

\section{Immunohistochemistry}

Immunohistochemistry was performed on selected samples of both proliferative and secretory phase endometrial tissue, using the peroxidase anti-peroxidase (PAP) method (Taylor et al. 2006). Sections of formalin-fixed, paraffin-embedded tissues were dewaxed, rehydrated and endogenous peroxidase was inactivated by treatment with $3 \%$ hydrogen peroxide in methanol for $30 \mathrm{~min}$ at room temperature. Citrate buffer was applied for epitope demasking. The polyclonal rabbit antieCG/eLH $\beta$ subunit primary antibody was obtained from Dr. Zimmermann, created using the specific oligopeptide NH2-Ala Glu Lys Glu Ala Cys Pro Ile Cys Ile Thr Phe Thr Thr Ser-COOH (amino acid 18-32) as antigen and produced by Biotrend $\mathrm{GmbH}$ (Köln, Germany) according to preparing the human endometrial CGB7 antibody described there (Zimmermann et al. 2012). The selected equine $C G$ antigen differs to the respective amino acid of the human $C G B(C G \beta)$ and $L H B$ $(\mathrm{LH} \beta)$ subunits at six positions (italics). The monospecific equine antibody purified by affinity chromatography shows no cross-reaction to hCG in Western blot and immunohistochemistry. The primary antibody $(1: 500)$ as well as the secondary antibody $(1: 100)$ and the PAP-complex $(1: 100)$ were diluted in tris-(hydroxymethyl)-aminomethane-buffered saline (TBS) containing $20 \%$ porcine serum. Sections were incubated with the primary antibody overnight at $4{ }^{\circ} \mathrm{C}$ and rinsed thoroughly with TBS. Sections were then treated with swine anti-rabbit immunoglobulin G (Dianova, Hamburg, Germany) for 30 min at room temperature. This procedure was followed by washing with TBS and incubation with the rabbit-PAP-complex (Dianova) for $30 \mathrm{~min}$ at room temperature. Afterwards, staining was performed using 3,3'-diaminobenzidine-tetrahydrochloride (DAB) (Fluka Feinchemikalien, Neu Ulm, Germany). Slides were counterstained with Papanicolaou's solution (Merck, Darmstadt, Germany). In negative control sections, the primary antibody was replaced by rabbit nonimmune serum diluted in TBS containing $20 \%$ porcine serum.

\section{Positive controls}

According to Eagle and Tortonese (2000) and Wooding et al. (2001), endometrial cup tissue of a 3 year old pregnant mare (fetus weighing $37 \mathrm{~g}$ and measuring $11.5 \mathrm{~cm}$ crown-rumplength) and pituitary gland tissue of a 11 year old mare served as positive controls for both molecular biological and immunohistochemical investigations. These controls were collected from euthanized horses and treated in the same way as de- 
scribed above. Data regarding the time of fertilization of the pregnant mare were not known, but according to Evans and Sack (1973) approximately 12 weeks of gestation can be concluded based on the crown-rump-length of $11.5 \mathrm{~cm}$. With respect to the histomorphological appearance of the endometrial cup tissue of this mare, the estimated gestation length of about 12 weeks is not contradictory to the common histomorphological characteristics of the development and regression of endometrial cups described by de Mestre et al. (2011).

\section{Results}

Table 1 shows the results of molecular biological investigation and histological examination of the specimens.

Histological evaluation of the endometrial functional morphology revealed early secretory $(n=4)$, late secretory $(n=2)$, transitory (secretory to proliferative) $(n=1)$, early proliferative $(n=1)$ and proliferative $(n=1)$ morphology. Most of the mares $(n=7)$ had different degrees of endometrosis. The 2 mares without endometrosis neither showed inflammation nor vascular degenerative changes. Of the 7 mares with endometrosis, 3 had non-suppurative superficial endometritis (lymphoplasmacytic infiltration of the endometrium, mainly restricted to the stratum compactum). Angiosclerosis could be detected in 4 mares.

By means of RT-PCR, mRNA of eCG/eLH $\beta$ subunit could be detected in 6 samples (Fig. 1). Sequencing of the PCR products of 5 samples was performed to confirm the specificity of the results obtained by molecular biological examinations. There was no correlation between functional morphology of the endometrium and eCG/eLH $\beta$ subunit mRNA expression.

eCG/eLH $\beta$ subunit could also be detected immunohistochemically (Fig. 2). Positive cytoplasmic reaction could be observed especially in glandular epithelial cells of both the proliferative and secretory phase. Immunostaining was also found in surface epithelium and the walls of blood vessels as well as in scattered stromal cells and in a few leukocytes. In the samples of the gravid endometrium which served as positive control, immunohistochemistry revealed comparable results. Particularly, immunolabelling could be detected in the cytoplasm of glandular epithelial cells both within and surrounding the endometrial cups (Fig. 3). Moreover, endometrial cup cells also showed positive reaction (Fig. 4). Slides of the pituitary gland used as positive control exhibited cytoplasmic immunostaining in several scattered cells of the pars distalis (Fig. 4).

\section{Discussion}

The objective of our work was to investigate whether the gene of the eCG/eLH $\beta$ subunit is transcribed in the endometrium of non-gravid mares. The results obtained in this study demonstrate that the equine endometrium is generally capa-

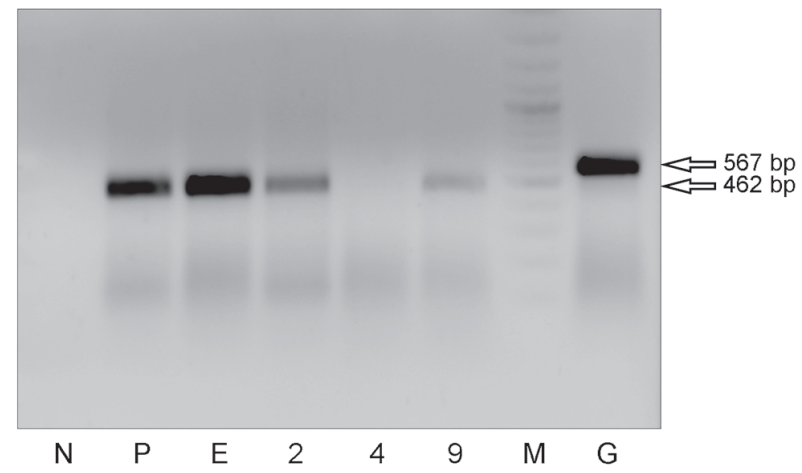

Fig. 1 Detection of eCG/eLH $\beta$ subunit mRNA by RT-PCR. Figure exemplifies the results obtained from 3 endometrial specimens (mares no. 2, 4 and 9). Note the lack of an amplicon in the sample of mare no. 4, which had been ascertained to be in late secretory phase by means of histopathological examination of formalin-fixed, paraffin-embedded endometrial tissue. Pituitary gland tissue (P) and endometrial cup tissue (E) were used as positive controls. $\mathrm{N}$ : negative control, using DEPC water. M: marker, 100 base pairs (bp). G: GAPDH.

Nachweis der mRNA der $\beta$-Untereinheit von eCG/eLH mittels RT-PCR. In der Abbildung sind exemplarisch die Ergebnisse von drei untersuchten Endometriumproben dargestellt. Auffällig ist hier insbesondere das Fehlen eines Amplifikats in der Probe von Stute 4, welche anhand der histopathologischen Untersuchung des formalinfixierten, paraffineingebetteten Gewebes der späten Sekretionsphase zugeordnet wurde. Als Positivkontrollen dienten Gewebe einer Hypophyse (P) sowie von Endometrial cups (E). N: Negativkontrolle unter Verwendung von DEPC-Wasser. M: Marker, 100 Basenpaare (bp). G: GAPDH.

Table 1 Histopathological examination of the endometrial specimens and detection of eCG/eLH $\beta$ subunit mRNA / Histopathologische Untersuchung der Endometriumproben und Nachweis der mRNA der $\beta$-Untereinheit von eCG/eLH.

\begin{tabular}{|c|c|c|c|c|c|c|c|}
\hline mare no. & age (years) & $\begin{array}{l}\text { month of } \\
\text { sampling }\end{array}$ & $\begin{array}{c}\text { functional morphology } \\
\text { of the endometrium }\end{array}$ & endometrosis & endometritis & angiosclerosis & RT-PCR \\
\hline 1 & 4 & June & early secr. & - & - & - & neg. \\
\hline 2 & 3 & June & early secr. & - & - & - & pos.* \\
\hline 3 & 3 & June & early secr. & + & - & - & neg. \\
\hline 4 & 18 & April & late secr. & ++ & - & +++ & neg. \\
\hline 5 & 14 & July & secr. - prolif. ${ }^{1}$ & + & + & - & pos.* \\
\hline 6 & 12 & August & early secr. & + & - & + & pos. \\
\hline 7 & 15 & April & early prolif. & ++ & - & + & pos.* \\
\hline 8 & 10 & April & late secr. & + & $+(+)$ & ++ & pos.* \\
\hline 9 & 12 & May & prolif. & + & + & + & pos.* \\
\hline
\end{tabular}

secr. $=$ secretory; prol. $=$ proliferative $;{ }^{1}=$ transition from secretory to proliferative phase $;-=$ absent; $+=$ mild $;+(+)=$ mild to moderate;

$++=$ moderate $;++=$ marked; neg. = negative; pos. $=$ positive ${ }^{*}=$ confirmed by sequencing 
ble of eCG/eLH $\beta$ subunit production not only during pregnancy, but also without the mare being pregnant.

Synthesis and secretion of hCG is known to take place in the uterine glandular and luminal epithelium of non-pregnant women almost exclusively during the secretory phase of the menstrual cycle (Alexander et al. 1998, Wolkersdörfer et al. 1998, Zimmermann et al. 2009, 2012). In contrast, endometrial hLH subunit mRNA expression is not detectable (Zimmermann et al. 2009). While the $\beta$ subunits of hCG and hLH can also be distinguished immunologically (Ghai et al. 1980), those of eCG and eLH possess an identical amino acid sequence as well as the same antigenic properties (Bousfield et al. 1987, Sugino et al. 1987, Wooding et al. $2001)$. Hence, the term eCG/eLH is used regarding our own molecular biological and immunohistochemical applications. The feature of the identical amino acid sequence of eCG and eLH led Stewart and Allen (1995) to challenge the distinctness of these two hormones. However, these authors conclude that the different glycosylation patterns justify a consideration as two separate hormones.

In two-thirds of our specimens, eCG/eLH $\beta$ subunit mRNA expression could be detected without showing obvious correlations to the functional morphology (secretory or proliferative phase) of the endometrium. Moreover, no amplicon was found in three specimens of secretory phase endometria (mares no. 1, 3 and 4). In two of these samples (mares no. 1 and 3), no or only mild degenerative alterations were detected. Therefore, the lack of transcription of the eCG/eLH $\beta$ subunit might possibly reflect alterations which are morphologically indiscernible, such as endocrine dysregulations or other functional disturbances. In women, decreased or absent hCG production is known to correlate with inadequate differ-

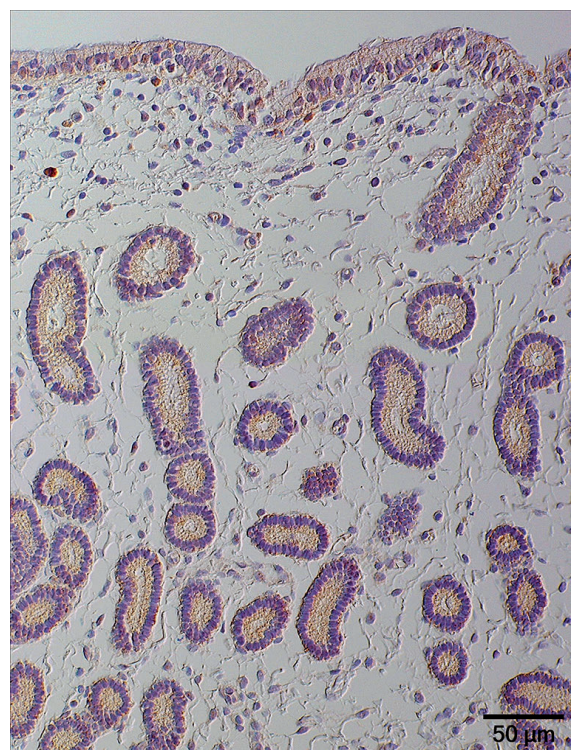

Fig. 2 Immunohistochemical detection of eCG/eLH $\beta$ subunit in proliferative phase endometrium. Immunostaining is especially located in the cytoplasm of glandular epithelial cells, but also in the surface epithelium as well as in scattered stromal cells and in a few leukocytes. Nomarski interference contrast.

Immunhistochemischer Nachweis der $\beta$-Untereinheit von eCG/eLH in der endometrialen Proliferationsphase. Das Reaktionsprodukt findet sich insbesondere im Zytoplasma der Drüsenepithelzellen, ist darüber hinaus jedoch auch im Oberflächenepithel sowie in vereinzelten Stromazellen und wenigen Leukozyten nachweisbar. Nomarski-Interferenzkontrast. entiation of the endometrium (Zimmermann et al. 2009). However, in the samples used in our study no morphological signs of endometrial maldifferentiation were evident.

We could also reveal the presence of the eCG/eLH $\beta$ subunit in the endometrium of non-gravid mares by immunohistochemical investigations of paraffin-embedded tissue. Our findings are similar to the reaction pattern seen in women (Alexander et al. 1998, Wolkersdörfer et al. 1998, Zimmermann et al. 2009).

Whereas the endometrial cups are currently generally believed to be the sole source of eCG in the mare (de Mestre et al. 2011, Antczak et al. 2013), a few authors argued the possibility of eCG production in cells of non-fetal origin (McFarlane et al. 1991a, Murphy and Martinuk 1991). Clegg et al. (1954) made the assumption that eCG is secreted by the epithelial cells of the uterine glands located within the endometrial cups, but not by the cup cells that have later been shown to be of fetal origin (Allen and Moor 1972). Comparable conclusions were drawn by Hernández-Jáuregui and González-Angulo (1975), who observed intracytoplasmic presence of eCG exclusively in glandular epithelial cells within the endometrial cups using immuofluorescence techniques. Although these authors declare the additional examination of endometrial tissue of one non-pregnant mare, they do neither mention the immunofluorescence features of this specimen nor the application of any positive control. However, in our work the endometrial cup cells as well as several cells in the pars distalis of the pituitary gland showed immunostaining and therefore served as positive controls according to the reports of Eagle and Tortonese (2000) and Wooding et al. (2001). Moreover, in our samples of the gravid endometrium epithelial cells of the uterine glands both within and surrounding the endometrial cups revealed positive reaction. This property resembles our immunohistochemical findings in the endometrium of non-gravid mares, where we were able to detect eCG/eLH $\beta$ subunit in the glandular epithelium. In

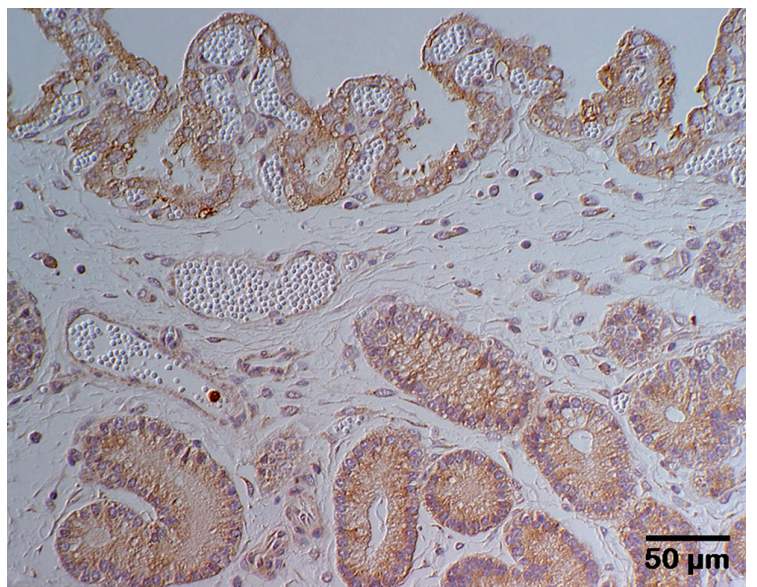

Fig. 3 Immunohistochemical detection of eCG/eLH $\beta$ subunit in cells of uterine glands located outside of the endometrial cups of a pregnant mare. The surface epithelium as well as some stromal cells and a few leukocytes also show positive reaction. Nomarski interference contrast.

Immunhistochemischer Nachweis der $\beta$-Untereinheit von eCG/eLH in Zellen außerhalb der Endometrial cups gelegener Uterindrüsen einer tragenden Stute. Das Oberflächenepithel, einige Stromazellen sowie wenige Leukozyten zeigen ebenfalls eine positive Reaktion. Nomarski-Interferenzkontrast. 
pregnant women, endometrial glandular epithelium has been shown to produce hCG (Zimmermann et al. 2003), suggesting a local immunomodulatory effect (Schumacher et al. 2009). In contrast to our results, Wooding et al. (2001) found eCG to be absent in glandular epithelial cells by means of immunohistochemical evaluation of endometrial tissue obtained from pregnant mares ranging from 37 to 50 days of gestation. Notably, these authors used a combined glutaraldehyde-formaldehyde fixation. However, glutaraldehyde may adversely affect antigenic properties of several proteins. The effects of glutaraldehyde fixation may depend on the particular antigen as well as on the concentration of the fixative (Griffiths 1993). Nevertheless, Wooding et al. (2001) could demonstrate immunostaining of both endometrial cup cells and pituitary gland cells using polyclonal antibodies against eCG. Moreover, these authors also confirmed the immunological similarity of eCG and eLH, as one and the same pituitary cell reacted with antibodies against both eCG and eLH.

Klein et al. (2010) report on both eLH $\beta$ subunit gene expression and immunohistochemical detection of $\beta$ subunit protein in equine endometrial samples taken during early pregnancy (day 13.5 of gestation) as well as in diestrus. The authors were able to observe up-regulation of gene expression in gravid endometrium compared to tissue obtained in diestrus. In conclusion, they draw a parallel between women and mares regarding possible paracrine effects of eLH on endometrial tissue during early pregnancy. While eLH $\beta$ subunit protein presence was detectable on day 13.5 of pregnancy by means of immunohistochemistry, only weak, if any, immunostaining was noticed in endometrial specimens of nongravid mares. Even in the samples of the pregnant mares, the protein was solely found in superficial epithelium. However, according to the product specifications of the distributor of the antibody used by Klein et al. (2010), the detection system seems to be rather nonspecific for eLH, as hCG $\beta$ subunit had been used for rabbit immunization and therefore the antibody is reported to crossreact with hLH only weakly. Moreover, eCG and hCG have been shown to feature little or no crossreactivity (Flux and Li 1965, Schams and Papkoff 1972, Christakos and Bahl 1979). At least to some extent, this might be due to an overall amino acid sequence homology of only

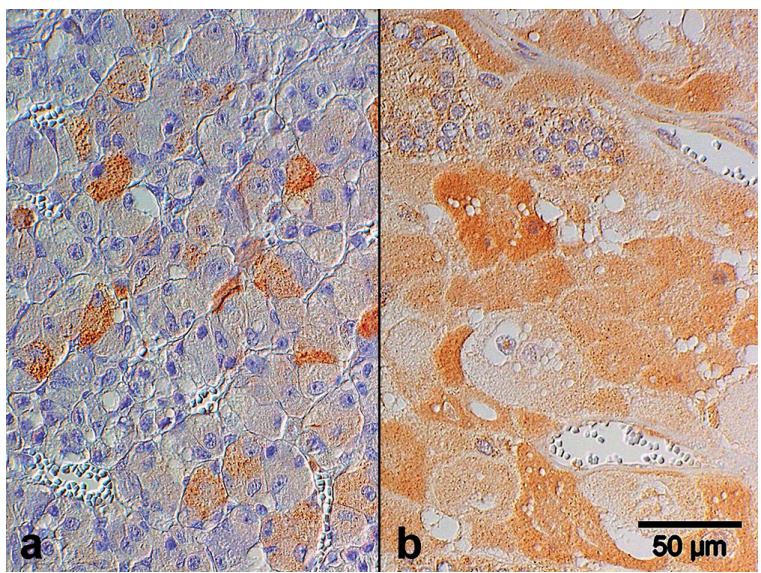

Fig. 4 Immunohistochemical detection of eCG/eLH $\beta$ subunit in pituitary gland cells (a) as well as in endometrial cup cells (b), serving as positive controls. Nomarski interference contrast.

Immunhistochemischer Nachweis der $\beta$-Untereinheit von eCG/eLH in Zellen der Hypophyse (a) sowie der Endometrial cups (b), welche als Positivkontrollen dienten. Nomarski-Interferenzkontrast.
$51 \%$ regarding the $\beta$ subunits of eCG and hCG (Sugino et al. 1987). Even between closely related species like donkey and horse, considerable differences exist in CG primary structure (Leigh and Stewart 1990).

The biological role of eCG in the horse is still not fully understood (Murphy 2012). However, eCG of endometrial cup origin acts as an agonist of ovarian LH receptors, leading to formation of accessory corpora lutea during equine pregnancy (Amoroso et al. 1948, Urwin and Allen 1982). Esmeraldino et al. (2010) provided evidence of the target structures of eCG/eLH in the equine uterus: compared to the winter anestrus, LH receptor expression in luminal and glandular epithelium is increased during the estrous cycle. Therefore, these authors hypothesize a possible role of LH concerning autocrine or paracrine regulation mechanisms in the endometrium of the mare. Our results suggest that similar conditions might also exist for eCG. Esmeraldino et al. (2010) did not detect any significant differences in LH receptor expression during the cyclic activity of the mare, i.e. between estrous and diestrous endometrium. Comparably, we did neither detect any dependency of eCG/eLH $\beta$ subunit production on the distinct stages of the endometrial cycle. Thus, the hormone might be produced in a constitutive rather than in a regulated manner. The endometrial cup cells are known to secrete eCG constitutively (de Mestre et al. 2011). In contrast, eLH is released in a cycle-dependent manner, revealing considerable differences between basal serum levels and the preovulatory surge (Alexander and Irvine 2011 ). eCG has been shown to exhibit a much lower binding affinity to ovarian $\mathrm{LH}$ receptors than pituitary eLH does, which is probably due to the differing carbohydrate moieties (Stewart and Allen 1979, Murphy and Martinuk 1991). Therefore, it seems unlikely that eCG synthesized in the nongravid endometrium might evoke a relevant endocrine effect on the ovaries, particularly as detectable blood serum levels during pregnancy do not occur before approximately five weeks of gestation (Allen 1969, Ginther 1992). The varying carbohydrate chains of the $\beta$ subunits of eCG and eLH are based on differing glycosylation enzymes expressed in the synthesizing cell types in the endometrial cups and the pituitary gland, respectively (Smith et al. 1993, Matsui et al. 1994). Thus, the carbohydrate content of the hormonal $\beta$ subunit detected in this study is likely to be dependent on the enzyme profile of the endometrial epithelium.

Although many studies, including the presented one, focus on the $\beta$ subunit of equine gonadotropic hormones, the $\alpha$ subunit has been shown to play a crucial role for the biological activity of the dimeric molecule (Papkoff 1974, Chopineau et al. 1997, 2004). Wolkersdörfer et al. (1998) suggested a circulating pool of free $\alpha$ subunits in women, being systemically available due to an excessive secretion into the blood stream by the pituitary gland (Hagen et al. 1976). However, the $\alpha$ subunit of hGC has been proven to be synthesized in the human endometrium, leading to an endometrial formation of the hCG heterodimer (Zimmermann et al. 2009).

In conclusion, this study for the first time demonstrates the equine endometrial glands to be capable of producing the eCG/eLH $\beta$ subunit in different stages of the endometrial cycle of non-gravid mares as well as during pregnancy. The relevance of these findings still has to be determined, par- 
ticularly with regard to biological aspects during the normal estrus cycle and in terms of functional disturbances of the endocrine regulatory circuit. However, our results suggest a paracrine role of eCG/eLH in the endometrium of the mare.

\section{Acknowledgment}

The authors thank Maritta Wipplinger for performing immunohistochemistry and the histology laboratory for excellent technical assistance.

\section{References}

Aggarwal B. B., Farmer S. W., Papkoff H., Stewart F., Allen W. R. (1980) Purification and characterization of donkey chorionic gonadotrophin. J. Endocrinol. 85, 449-455

Alexander H., Zimmermann G., Wolkersdörfer G. W., Biesold C., Lehmann M., Einenkel J., Pretzsch G., Baier D. (1998) Utero-ovarian interaction in the regulation of reproductive function. Hum. Reprod. Update. 4, 550-559

Alexander S. L., Irvine C. H. G. (2011) FSH and LH. In: Equine Reproduction. McKinnon A. O., Squires E. L., Vaala W. E. and Varner D. D. (eds.), Wiley-Blackwell, Hoboken, NJ, USA, 2nd ed. $1619-1630$

Allen W. R. (1969) The immunological measurement of pregnant mare serum gonadotrophin. J. Endocrinol. 43, 593-598

Allen W. R., Hamilton D. W., Moor R. M. (1973) The origin of equine endometrial cups. II. Invasion of the endometrium by trophoblast. Anat. Rec. 177, 485-501

Allen W. R., Moor R. M. (1972) The origin of the equine endometrial cups. I. Production of PMSG by fetal trophoblast cells. J. Reprod. Fertil. 29, 313-316

Amoroso E. C., Hancock J. L., Rowlands I. W. (1948) Ovarian activity in the pregnant mare. Nature 161, 355-356

Antczak D. F, de Mestre A. M., Wilsher S., Allen W. R. (2013) The equine endometrial cup reaction: a fetomaternal signal of significance. Annu. Rev. Anim. Biosci. 1, 8.1-8.24

Bousfield G. R., Butnev V. Y., Gotschall R. R., Baker V. L., Moore W. T. (1996) Structural features of mammalian gonadotropins. Mol. Cell. Endocrinol. 125, 3-19

Bousfield G. R., Liu W. K., Sugino H., Ward D. N. (1987) Structural studies on equine glycoprotein hormones. Amino acid sequence of equine lutropin $\beta$-subunit. J. Biol. Chem. 262, 8610-8620

Chopineau M., Martinat N., Gibrat J. F., Galet C., Lecompte F., FouIon-Gauze F., Pourchet C., Guillou F., Combarnous Y. (2004) Identification of amino-acids in the $\beta$-subunit first and third loops that are crucial for the heterospecific follicle-stimulating hormone activity of equid luteinizing hormone/choriogonadotropin. Eur. J. Endocrinol. 150, 877-884

Chopineau M., Martinat N., Marichatou H., Troispoux C., AugeGouillou C., Stewart F, Combarnous Y., Guillou F. (1997) Evidence that the $\alpha$-subunit influences the specificity of receptor binding of the equine gonadotrophins. J. Endocrinol. 155, 241-245

Chopineau M., Martinat N., Pourchet C., Stewart F., Combarnous Y., Guillou F. (1999) Cloning, sequencing and functional expression of zebra (Equus burchelli) LH. J. Reprod. Fertil. 115, 159-166

Christakos S., Bahl O. P. (1979) Pregnant mare serum gonadotropin. Purification and physicochemical, biological, and immunological characterization. J. Biol. Chem. 254, 4253-4261

Clegg M. T., Boda J. M., Cole H. H. (1954) The endometrial cups and allantochorionic pouches in the mare with emphasis on the source of equine gonadotrophin. Endocrinology 54 448-463

Cole L. A. (2012) hCG, the wonder of today's science. Reprod. Biol. Endocrinol. 10, 24 de Mestre A. M., Antczak D. F., Allen W. R. (2011) Equine chorionic gonadotropin (eCG). In: Equine Reproduction. McKinnon A. O., Squires E. L., Vaala W. E. and Varner D. D. (eds.), Wiley-Blackwell, Hoboken, NJ, USA, 2nd ed., 1648-1664

Eagle R. C., Tortonese D. J. (2000) Characterization and distribution of gonadotrophs in the pars distalis and pars tuberalis of the equine pituitary gland during the estrous cycle and seasonal anestrus. Biol. Reprod. 63, 826-832

Erdmann S., Ricken A., Merkwitz C., Struman I., Castino R., Hummitzsch K., Gaunitz F., Isidoro C., Martial J., Spanel-Borowski K. (2007) The expression of prolactin and its cathepsin D-mediated cleavage in the bovine corpus luteum vary with the estrous cycle. Am. J. Physiol. Endocrinol. Metab. 293, E1365-E1377

Esmeraldino A. T., Malschitzky E., Fiala S. M., Santarém L., Wolf C. A., Jobim M. I. M., Gregory R. M., Mattos R. C. (2010) Immunohistochemical identification of luteinizing hormone receptors in the extra-gonadal reproductive tract of the mare. Tenth International Symposium on Equine Reproduction, Lexington, KY, USA, Abstract in: Anim. Reprod. Sci. 121S, S38-S39

Evans H. E., Sack W. O. (1973) Prenatal development of domestic and laboratory mammals: growth curves, external features and selected references. Anat. Histol. Embryol. 2, 1 1-45

Flux D. S., Li C. H. (1965) Immunological cross reactions among gonadotrophins. Acta Endocrinol. (Copenh.) 48, 61-71

Ghai R. D., Mise T., Pandian M. R., Bahl O. P. (1980) Immunological properties of the $\beta$-subunit of human chorionic gonadotropin. I. Effect of chemical and enzymatic modifications. Endocrinology $107,1556-1563$

Ginther O. J. (1992) Endocrinology of pregnancy. In: Reproductive biology of the mare - basic and applied aspects. Ginther $O$. J. (ed.), Equiservices, Cross Plains, WI, USA, 2nd ed., 419-456

Griffiths $G$. (1993) Fixation for fine structure preservation and immunocytochemistry. In: Fine structure immunocytochemistry. Griffiths G. (ed.), Springer, Berlin, Heidelberg, Germany; 26-89

Hagen C., McNatty K. P., McNeilly A. S. (1976) Immunoreactive $\alpha$ and $\beta$-subunits of luteinizing hormone in human peripheral blood and follicular fluid throughout the menstrual cycle, and their effect on the secretion rate of progesterone by human granulosa cells in tissue culture. J. Endocrinol. 69, 33-46

Hernández-Jáuregui P., González-Angulo A. (1975) The ultrastructure of endometrial cups in pregnant mares. J. Reprod. Fertil. Suppl. 23, 401-404

Kenney R. M., Doig P. A. (1986) Equine Endometrial Biopsy. In: Current therapy in theriogenology. Morrow D. A. (ed.), WB Saunders, Philadelphia, PA, USA, 2nd ed., 723-729

Klein C., Scoggin K. E., Ealy A. D., Troedsson M. H. T. (2010) Transcriptional profiling of equine endometrium during the time of maternal recognition of pregnancy. Biol. Reprod. 83, 102-113

Leigh S. E. A., Stewart F. (1990) Partial cDNA sequence for the donkey chorionic gonadotrophin- $\beta$ subunit suggests evolution from an ancestral LH- $\beta$ gene. J. Mol. Endocrinol. 4, 143-150

Matsui T., Mizuochi T., Titani K., Okinaga T., Hoshi M., Bousfield G. R., Sugino H., Ward D. N. (1994) Structural analysis of N-linked oligosaccharides of equine chorionic gonadotropin and lutropin $\beta$-subunits. Biochemistry 33, 14039-14048

Matsui T., Sugino H., Miura M., Bousfield G. R., Ward D. N., Titani K., Mizuochi T. (1991) $\beta$-subunits of equine chorionic gonadotropin and lutenizing hormone with an identical amino acid sequence have different asparagine-linked oligosaccharide chains. Biochem. Biophys. Res. Commun. 174, 940-945

McFarlane J. R., Coulson S. A., Papkoff H. (1991 a) Biological and immunoactive substances resembling chorionic gonadotropin are present in full-term horse and zebra placentas. Biol. Reprod. 45, 343-349

McFarlane J. R., Czekala N. M., Papkoff H. (1991b) Zebra chorionic gonadotropin: partial purification and characterization. Biol. Reprod. 44, 827-833

Mulisch M., Welsch U. (2010) Romeis Mikroskopische Technik. Spektrum Akademischer Verlag, Heidelberg, Germany, 18th ed.

Murphy B. D. (2012) Equine chorionic gonadotropin: an enigmatic but essential tool. Anim. Reprod. 9, 223-230 
Murphy B. D., Martinuk S. D. (1 191) Equine chorionic gonadotropin. Endocr. Rev. 12, 27-44

Papkoff H. (1974) Chemical and biological properties of the subunits of pregnant mare serum gonadotropin. Biochem. Biophys. Res. Commun. 58, 397-404

Pierce J. G., Parsons T. F. (1981) Glycoprotein hormones: structure and function. Annu. Rev. Biochem. 50, 465-495

Schams D., Papkoff H. (1972) Chemical and immunochemical studies on pregnant mare serum gonadotropin. Biochim. Biophys. Acta 263, 139-148

Schoon H.-A., Schoon D., Klug E. (1992) Uterusbiopsien als Hilfsmittel für Diagnose und Prognose von Fertilitätsstörungen der Stute. Pferdeheilkunde 8, 355-362

Schoon H.-A., Schoon D., Klug E. (1997) Die Endometriumbiopsie bei der Stute im klinisch-gynäkologischen Kontext. Pferdeheilkunde 13, 453-464

Schumacher A., Brachwitz N., Sohr S., Engeland K., Langwisch S., Dolaptchieva M., Alexander T., Taran A., Malfertheiner S. F., Costa S.-D., Zimmermann G., Nitschke C., Volk H.-D., Alexander H., Gunzer M., Zenclussen A. C. (2009) Human chorionic gonadotropin attracts regulatory $T$ cells into the fetal-maternal interface during early human pregnancy. J. Immunol. 182, 5488-5497

Sherman G. B., Wolfe M. W., Farmerie T. A., Clay C. M., Threadgill D. S., Sharp D. C., Nilson J. H. (1992) A single gene encodes the $\beta$-subunits of equine luteinizing hormone and chorionic gonadotropin. Mol. Endocrinol. 6, 951-959

Smith P. L., Bousfield G. R., Kumar S., Fiete D., Baenziger J. U. (1993) Equine lutropin and chorionic gonadotropin bear oligosaccharides terminating with $\mathrm{SO}_{4}-4-\mathrm{GalNAc}$ and $\mathrm{Sia} \alpha 2,3 \mathrm{Gal}$, respectively. J. Biol. Chem. 268, 795-802

Stewart F, Allen W. R. (1979) The binding of FSH, LH and PMSG to equine gonadal tissues. J. Reprod. Fertil. Suppl. 27, 431-440

Stewart F., Allen W. R. (1995) Comparative aspects of the evolution and function of the chorionic gonadotrophins. Reprod. Dom. Anim. 30, 231-239

Sugino H., Bousfield G. R., Moore Jr. W. T., Ward D. N. (1987) Structural studies on equine glycoprotein hormones. Amino acid sequence of equine chorionic gonadotropin $\beta$-subunit. J. Biol. Chem. 262, 8603-8609

Taylor C. R., Shi S. R., Barr N. J. (2006) Techniques of immunohistochemistry: principles, pitfalls and standardization. In: Diagnostic immunohistochemistry. Dabbs D. J. (ed.), Elsevier, Philadelphia, PA, USA, 2nd ed., 1-42

Urwin V. E., Allen W. R. (1982) Pituitary and chorionic gonadotrophic control of ovarian function during early pregnancy in equids. J. Reprod. Fertil. Suppl. 32, 371-381

Wolkersdörfer G. W., Bornstein S. R., Hilbers U., Zimmermann G., Biesold C., Lehmann M., Alexander H. (1998) The presence of chorionic gonadotrophin $\beta$ subunit in normal cyclic human endometrium. Mol. Hum. Reprod. 4, 179-184

Wooding F. B., Morgan G., Fowden A. L., Allen W. R. (2001) A structural and immunological study of chorionic gonadotrophin production by equine trophoblast girdle and cup cells. Placenta 22, 749-767
Zimmermann G., Ackermann W., Alexander H. (2009) Epithelial human chorionic gonadotropin is expressed and produced in human secretory endometrium during the normal menstrual cycle. Biol. Reprod. 80, 1053-1065

Zimmermann G., Ackermann W., Alexander H. (2012) Expression and production of human chorionic gonadotropin (hCG) in the normal secretory endometrium: evidence of CGB7 and/or CGB6 beta hCG subunit gene expression. Biol. Reprod. 86, 87 (1-14)

Zimmermann G., Baier D., Majer J., Alexander H. (2003) Expression of beta hCG and alpha CG mRNA and hCG hormone in human decidual tissue in patients during tubal pregnancy. Mol. Hum. Reprod. 9, 81-89

Transkription des Gens der $\beta$-Untereinheit von equinem Choriongonadotropin/Luteinisierendem Hormon im Endometrium nicht-tragender Stuten

Nach bisherigem Kenntnisstand wird equines Choriongonadotropin (eCG) durch Zellen fetalen Ursprungs und daher ausschließlich während der Trächtigkeit in den sogenannten Endometrial cups synthetisiert. Im Endometrium der Frau findet die Sekretion eines CGB7-genspezifischen humanen Choriongonadotropins ( $\mathrm{hCG}$ ) bereits während der normalen sekretorischen Phase im Drüsenepithel, das heißt unabhängig von einer einsetzenden Schwangerschaft statt. Daher sollte in der vorliegenden Studie die Transkription des Gens der bekannten $\beta$-Untereinheit von eCG bzw. equinem Luteinisierendem Hormon (eLH) mit ihren beiden identischen mRNA-Sequenzen auch im Endometrium nicht-gravider Stuten überprüft werden. Dazu wurden native Endometrien von 9 Stuten mittels RT-PCR auf eine mögliche Expression der mRNA der $\beta$-Untereinheit von eCG bzw. eLH untersucht. Anhand formalinfixierter, paraffineingebetteter Proben dieser Uteri erfolgte die histologische Bestimmung des Zyklusstandes (Sekretions- oder Proliferationsmorphologie des Endometriums). Zusätzlich wurden sowohl proliferativ als auch sekretorisch differenzierte Endometrien immunhistochemisch unter Verwendung eines neuen monospezifischen polyklonalen Kaninchen-anti-eCG $\beta$ /eLH $\beta$-Antikörpers untersucht. In 6 Proben konnte die Transkription des Gens der $\beta$-Untereinheit von eCG/eLH festgestellt werden, wobei sich sowohl in der Proliferations- als auch in der Sekretionsphase Amplifikate nachweisen ließen. Im Rahmen der immunhistochemischen Untersuchungen konnte die hormonelle $\beta$-Untereinheit intrazytoplasmatisch nachgewiesen werden, wobei die Reaktionsprodukte insbesondere in den Epithelzellen der Uterindrüsen lokalisiert waren. Die vorliegenden Ergebnisse deuten auf eine mögliche parakrine Funktion von eCG bzw. eLH im Endometrium der Stute hin, wenngleich weiterer Klärungsbedarf hinsichtlich der biologischen Relevanz der erhobenen Befunde besteht, insbesondere hinsichtlich funktioneller Aspekte im Verlauf des ungestörten Reproduktionsgeschehens sowie bei Dysfunktionen der endokrinen Regelkreise.

Schlüsselwörter: eCG / eLH / mRNA / Pferd / Uterus / PCR / Immunhistologie / Reproduktion 